\title{
ANALISIS PENYEBAB BANJIR KELURAHAN JATAKE - TANGERANG
}

\author{
Bryan Jeremia Parulian Harianja ${ }^{1}$ dan Wati Asriningsih Pranoto ${ }^{2}$
}

\author{
${ }^{1}$ Program Studi Sarjana Teknik Sipil, Universitas Tarumanagara, Jl. Letjen S. Parman No.1 Jakarta \\ Bryan.325160190@stu.untar.ac.id \\ ${ }^{2}$ Program Studi Sarjana Teknik Sipil, Universitas Tarumanagara, Jl. Letjen S. Parman No.1 Jakarta \\ watip@ft.untar.ac.id
}

\begin{abstract}
A flood is a natural disaster that occurs due to various factors, and there are lots of losses caused by flooding. In the Jatake-Tangerang district, floods were recorded as high as 30-50 cm during February 2020. This study aims to determine the factors that cause flooding in the area to find solutions. In this study, several things need to be analyzed: rainfall, channel capacity, and existing channel conditions. Rainfall was analyzed using the Chi-Square and Kolmogorov-Smirnov methods to determine the type of distribution to be used. The existing plan's capacity is analyzed using the Manning method to determine the discharge, which will be compared with the discharge due to rainfall that occurs using the rational method. Based on the results of the calculation of 6 of the 73 channels reviewed, it cannot accommodate the discharge due to the rainfall that occurs. It is necessary to plan a new channel to change the channel's dimensions that do not meet. After the analysis was carried out, it could be concluded that the flooding in the Jatake-Tangerang area was caused by a lack of capacity of the existing canal, area contours, garbage, and sediment at the bottom of the channel.
\end{abstract}

Keywords: flood; drainage; Manning; Jatake

\begin{abstract}
ABSTRAK
Banjir merupakan salah satu bencana alam yang terjadi karena berbagai faktor dan banyak sekali kerugian yang ditimbulkan akibat banjir. Di wilayah Kelurahan Jatake-Tangerang tercatat mengalami banjir setinggi $30-50 \mathrm{~cm}$ selama bulan Februari 2020. Penelitian ini bertujuan untuk mengetahui faktor penyebab terjadinya banjir di daerah tersebut sehingga bisa dicari solusinya. Dalam penelitian ini ada beberapa hal yang perlu dianalisis yaitu curah hujan, kapasitas saluran dan kondisi saluran eksisting. Curah hujan dianalisis dengan metode Chi-Square dan KolmogorovSmirnov untuk menentukan jenis distribusi yang akan digunakan. Kapasitas rencana eksisting dianalisis dengan metode Manning untuk mengetahui debitnya yang akan dibandingkan dengan debit akibat curah hujan yang terjadi menggunakan metode rasional. Berdasarkan hasil perhitungan 6 dari 73 saluran yang ditinjau tidak mampu menampung debit akibat curah hujan yang terjadi, maka perlu dilakukan perencanaan saluran baru untuk mengubah dimensi saluran yang tidak memenuhi. Setelah analisis dilakukan dapat disimpulkan bahwa banjir di kawasan Jatake-Tangerang disebabkan oleh kurangnya kapasitas saluran eksisting, kontur wilayah, sampah dan sedimen di dasar saluran.
\end{abstract}

Kata kunci: banjir; drainase; Manning; Jatake

\section{PENDAHULUAN}

Jatake merupakan salah satu Kelurahan yang terletak di Kecamatan Jatiuwung, Kota Tangerang, Banten, Indonesia. Kelurahan Jatake memiliki luas wilayah 1,4 Km² dengan jumlah penduduk 16.137 jiwa (Badan Pusat Statistik Kota Tangerang). Kelurahan Jatake merupakan sebuah daerah industri dan pemukiman warga. Daerah ini merupakan salah satu daerah yang terkena genangan air dalam jangka waktu yang cukup lama pada periode 3 februari 2020 dan 25 februari 2020. Sebaran daerah banjir pada Kelurahan Jatake dapat dilihat pada Gambar 1. 


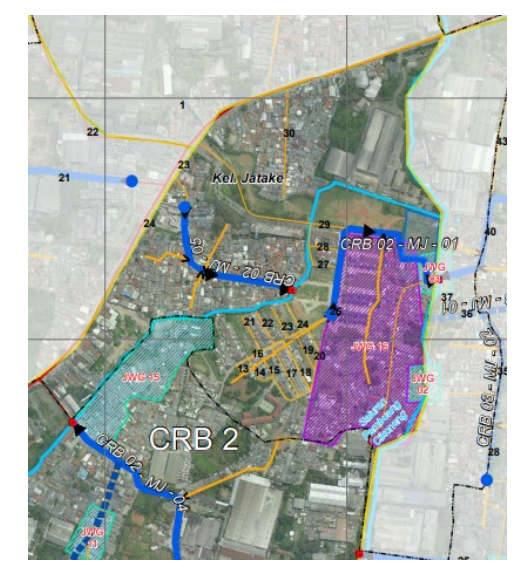

Gambar 1. Peta sebaran titik banjir Kelurahan Jatake-Tangerang

Dalam Jurnal ini difokuskan pada daerah yang terkena genangan ditandai dengan garis arsir berwarna ungu pada gambar.

Berdasarkan uraian diatas maka permasalahan pada jurnal ini dirumuskan sebagai berikut:

- Apakah kapasitas saluran eksisting dapat menampung debit air dari curah hujan yang terjadi pada periode ulang 2,5,10,20 tahun dan 25 Februari 2020?

- Periode ulang berapa yang digunakan dalam perhitungan debit saluran eksisting?

- Apa penyebab genangan air bisa terjadi di Kelurahan Jatake Kota Tangerang?

Tujuan Penelitian dari jurnal ini adalah sebagai berikut:

- Mengetahui kapasitas saluran eksisting dapat menampung debit air atau tidak dari curah hujan yang terjadi pada periode ulang 2,5,10,20 tahun dan 25 Februari 2020 .

- Mengetahui periode ulang berapa yang digunakan dalam perhitungan debit saluran eksisting.

- Mengetahui penyebab genangan air bisa terjadi di Kelurahan Jatake Kota Tangerang.

\section{Banjir}

Sesuai dengan Peraturan Pemerintah Republik Indonesia Nomor 38 Tahun 2011 tentang Sungai dinyatakan bahwa banjir adalah peristiwa meluapnya air sungai melebihi palung sungai. Banjir merupakan kejadian alam yang dihasilkan dari curah hujan yang tinggi dan dapat berakibat buruk sebagai akibat dari perubahan tata guna lahan (Flemming, 2002).

\section{Hujan Rencana}

Dalam menentukan besar hujan rencana dibutuhkan data hujan jangka pendek atau data hujan harian maksimum, untuk kemudian dianalisis menggunakan beberapa macam distribusi frekuensi. Ada empat jenis distribusi yang banyak digunakan dalam menghitung curah hujan rencana (Upono and Kusumawardani, 2016)

Dalam menghitung curah hujan rencana ada empat jenis distibusi yang banyak digunakan, adalah sebagai berikut:

- Distribusi Normal

Rumus yang digunakan dalam perhitungan ditribusi normal adalah:

$$
\mathrm{X}_{\mathrm{t}}=\overline{\mathrm{X}}+\mathrm{z} \cdot \mathrm{S}_{\mathrm{x}}
$$

Dengan $\mathrm{X}_{\mathrm{t}}=$ curah hujan rencana $(\mathrm{mm} /$ hari $), \overline{\mathrm{X}}=$ curah hujan maksimum rata-rata $(\mathrm{mm} / \mathrm{hari}), \mathrm{S}_{\mathrm{x}}=$ Standar deviasi, $\mathrm{z}=$ faktor frekuensi.

- Distribusi Log Normal

Rumus yang digunakan dalam perhitungan ditribusi log normal adalah:

$$
\log X_{t}=\log \bar{X}+K_{t} \cdot S \log X
$$


Dengan $\log X_{t}=$ harga logaritmik curah hujan rencana $(\mathrm{mm} /$ hari), $\log \bar{X}=$ harga rata-rata logaritmik $S L o g X=$ harga logaritmik standar deviasi, $\mathrm{K}_{\mathrm{t}}=$ standar variabel untuk periode ulang.

- Distribusi Log Pearson III

Rumus yang digunakan dalam perhitungan ditribusi log pearson III adalah:

$$
\log \overline{\mathrm{X}}=\frac{\sum_{\mathrm{i}=1}^{\mathrm{n}} \log \left(\mathrm{X}_{\mathrm{i}}\right)}{\mathrm{n}} \operatorname{SLog} \mathrm{X}
$$

Dengan $\log \bar{X}=$ harga rata-rata logaritmik ( $\mathrm{mm} /$ hari), $\mathrm{X}_{\mathrm{i}}=$ nilai curah hujan $(\mathrm{mm} / \mathrm{hari}), \mathrm{n}=$ jumlah data, $\mathrm{SLogX}=$ harga logaritmik standar deviasi.

- Distribusi Gumbel

Rumus yang digunakan dalam perhitungan ditribusi gumbel adalah:

$$
X_{t}=\bar{x}+\frac{\left(Y_{t}-Y_{n}\right)}{S_{n}} \times S_{x}
$$

Dengan $X_{t}=$ curah hujan rencana $(\mathrm{mm} /$ hari $), \bar{X}=$ curah hujan maksimum rata-rata $(\mathrm{mm} / \mathrm{hari}), \mathrm{S}_{\mathrm{x}}=$ standar deviasi, $\mathrm{Y}_{\mathrm{t}}=$ reduced variable, $\mathrm{Y}_{\mathrm{n}}=$ reduced mean, $\mathrm{S}_{\mathrm{n}}=$ reduced standard deviation.

\section{Pemilihan Fungsi Distribusi}

Pemilihan fungsi distribusi diuji dengan uji kecocokan menggunakan metode pengujian dan dengan, confidence interval (tingkat interval kepercayaan) tertentu dapat menggunakan metode Chi-Square dan metode KolmogorovSmirnov sebagai berikut (SNI 2415:2016):

- Chi-Square

Metode ini menganggap pengamatan membentuk variable acak dan dilakukan secara statistik dengani mengikuti kurva distribusi chi square dengan derajat kebebasan k-p-1, dengan $\mathrm{p}$ merupakan jumlah parameter yang diesitimasi dari data. Uji statistik ini berdasarkan pada bobot jumlah kuadrat perbedaan antara pengamatan dan teoritisnya yang dibagi dalam kelompok kelas.

Jika hasilnya $X \frac{k}{n}$ besar menunjukkan bahwa distribusi yang dipakai tidak cocok, tetapi uji ini dapat memberikan hasil yang baik jika mempunyai data yang panjang.

\section{- Kolmogorov-Smirnof}

Menghindarkan hilangnya informasi data pada uji Chi-Square akibat pengelompokan dalam kelas-kelas interval, ada beberapa metode lain yang telah dikembangkan. Salah satu metode yang sering digunakan adalah uji Kolmogorov-Smirnov. Uji kecocokan ini adalah uji kecocokan "non parametric" karena tidak mengikuti distribusi tertentu. Uji ini menghitung besarnya jarak maksimum secara vertikal antara pengamatan dan teotitisnya dari distribusi sampelnya. Distribusi dapat dikatakan cocok jika nilai $\mathrm{Dn}<\mathrm{D}$ kritisnya pada derajat kepercayaan yang diinginkan.

\section{Intensitas Hujan}

Intensitas hujan adalah besaran ketinggian hujan yang ditetapkan sebagai harga perencanaan yang memperhatikan periode ulang yang dihitung dengan metode yang lazim dalam analisis hidrologi (SNI 8456:2017). Rumus yang digunakan:

$$
I=\frac{R_{24}}{24}\left(\frac{24}{t}\right)^{\frac{2}{3}}
$$

Dengan $\mathrm{I}=$ intensitas hujan $(\mathrm{mm} / \mathrm{jam}), \mathrm{tc}=$ lamanya curah hujan $(\mathrm{jam}), \mathrm{R} 24=$ curah hujan maksimum dalam 24 jam $(\mathrm{mm})$.

\section{Debit rancangan dengan metode rasional}

Persamaan menurut (SNI 2415:2016) yang digunakan:

$$
\mathrm{Qp}=0,00278 \text { C.I.A }
$$

Dengan $\mathrm{Qp}=$ debit puncak $\left(\mathrm{m}^{3} / \mathrm{dt}\right), \mathrm{C}=$ Koefisien limpasan, $\mathrm{A}=$ luas daerah pengaliran saluran/DPSal (ha), $\mathrm{I}=$ intensitas hujan selama waktu konsentrasi ( $\mathrm{mm} / \mathrm{jam})$ 


\section{HEC-RAS}

HEC-RAS merupakan program aplikasi untuk memodelkan aliran air di sungai, River Analysis System (RAS), yang dibuat oleh Hydrologic Engineering Center (HEC) yang merupakan satu divisi di dalam Institute for Water Resources (IWR). HEC-RAS merupakan model satu dimensi aliran permanen maupun tak permanen (Istiarto, 2010).

\section{METODE PENELITIAN}

Data yang diperlukan dalam penelitian ini sebagai berikut:

- Peta Sebaran Titik Banjir di Kelurahan Jatake dari Dinas Pekerjaan Umum dan Penataan Ruang Kota Tangerang.

- Data Curah Hujan Harian Maksimum stasiun Geofisika Tangerang selama 10 tahun dari Badan Meteorologi Klimatologi dan Geofisika.

- Peta Jaringan Drainase di Kelurahan Jatake dari Dinas Pekerjaan Umum dan Penataan Ruang Kota Tangerang.

- Spesifikasi saluran eksisting di Kelurahan Jatake dari pengukuran langsung di lapangan.

- Peta Topografi Kelurahan Jatake dari Dinas Pekerjaan Umum dan Penataan Ruang Kota Tangerang.

Berikut pengolahan data yang dilakukan:

- Mengambil dan mengolah data curah hujan maksimum harian setiap tahun selama 10 tahun

- Melakukan pengujian kecocokan fungsi distribusi dengan menggunakan metode Chi-Square dan Kolmogorov-Smirnov.

- Menghitung frekuensi curah hujan dengan distribusi yang sudah diuji dengan pengujian kecocokan fungsi distribusi.

- Melakukan Perhitungan kapasitas saluran drainase eksisting.

- Menghitung debit limpasan dengan metode Rasional.

- Menganalisis debit saluran eksisting mampu menampung debit limpasan dengan metode Rasional atau tidak.

- Menganalisis saluran drainase rencana.

- Melakukan pemodelan terhadap saluran rencana dengan aplikasi HEC-RAS.

\section{HASIL DAN PEMBAHASAN}

\section{Peta jaringan drainase dan daerah tangkapan air}

Pada Gambar 2 adalah peta jaringan drainase dan daerah tangkapan air untuk setiap saluran yang ada di wilayah Magnolia Recidence dan Kampung Cikoneng Ilir yang dijadikan sebagai lokasi penelitian.

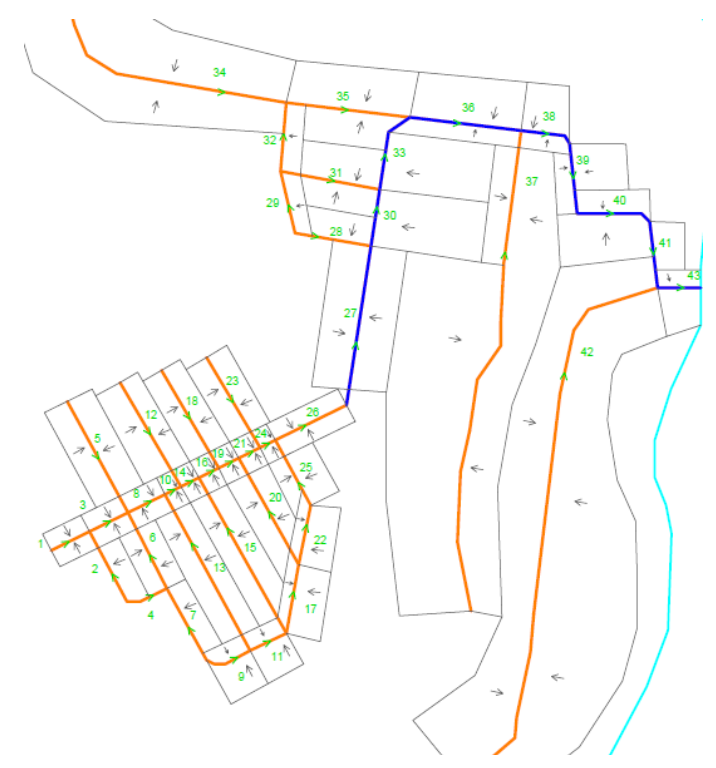

Gambar 2. Peta jaringan drainase dan daerah tangkapan air 


\section{Perhitungan curah hujan rencana}

Hasil dari pengujian distrbusi mengunakan metode Chi-Square dan metode Kolmogorov-Smirnov dapat dilihat pada Tabel 1.

Tabel 1. Hasil rekapitulasi uji Chi-Square dan Kolmogorov-Smirnov

\begin{tabular}{|c|c|c|c|c|c|c|c|}
\hline \multirow{2}{*}{ No } & \multirow{2}{*}{ Distribusi } & \multicolumn{2}{|c|}{ Chi-Square } & \multirow{2}{*}{ Kesimpulan } & \multicolumn{2}{|c|}{ Kolmogorov-Smirnov } & \multirow{2}{*}{ Kesimpulan } \\
\hline & & $\mathrm{X}^{2}$ & $\mathrm{X}^{2} \mathrm{Cr}$ & & Do & Dmax & \\
\hline 1 & Normal & 5,991 & 11 & Tidak Diterima & 0,41 & 0,1212 & Diterima \\
\hline 2 & Log Normal & 5,991 & 4 & Diterima & 0,41 & 0,1258 & Diterima \\
\hline 3 & $\begin{array}{c}\text { Log Pearson } \\
\text { III }\end{array}$ & 5,991 & 3 & Diterima & 0,41 & 0,1268 & Diterima \\
\hline 4 & Gumbel & 5,991 & 4 & Diterima & 0,41 & 0,4562 & Tidak Diterima \\
\hline
\end{tabular}

Dari tabel diatas maka dapat disimpulkan distribusi yang digunakan adalah distribusi log pearson III. Hasil perhitungan curah hujan rencana dengan metode distribusi $\log$ pearson III dapay dilihat pada Tabel 2 berikut.

Tabel 2. Curah hujan rencana

\begin{tabular}{cccc}
\hline Tahun & $\mathrm{k}$ & $\log \mathrm{Rr}$ & $\mathrm{Rr}(\mathrm{mm})$ \\
\hline 2 & 0,026 & 1,98763 & 97,19 \\
5 & 0,843 & 2,068447 & 117,07 \\
10 & 1,263 & 2,109988 & 128,82 \\
20 & 1,565 & 2,139858 & 137,99 \\
\hline
\end{tabular}

Berdasarkan Permen PU Nomor 12/PRT/M/2014 tentang Penyelenggaraan Sistem Drainase Perkotaan, periode ulang yang digunakan untuk daerah tangkapan air kurang dari 10 Ha di kota metropolitan adalah 2 tahun (Kementerian Pekerjaan Umum).

\section{Perhitungan kapasitas saluran eksisting}

Perhitungan debit saluran eksisting menggunakan metode manning sedangkan debit rancangan menggunakan metode rasional, keduanya dibandingkan untuk melihat apakah saluran eksisiting mampu menampung debit limpasan. Hasil perhitungan dapat dilihat pada Tabel 3.

Tabel 3. Analisis saluran eksisitng

\begin{tabular}{cccccccc}
\hline $\begin{array}{c}\text { No. } \\
\text { Saluran }\end{array}$ & $\begin{array}{c}\text { Posisi } \\
\text { saluran }\end{array}$ & $\begin{array}{c}\text { Panjang } \\
(\mathrm{m})\end{array}$ & $\begin{array}{c}\text { Lebar } \\
(\mathrm{m})\end{array}$ & $\begin{array}{c}\text { Kedalaman } \\
(\mathrm{m})\end{array}$ & $\begin{array}{c}\text { Debit } \\
\text { Eksisiting } \\
\left(\mathrm{m}^{3} / \mathrm{s}\right)\end{array}$ & $\begin{array}{c}\text { Debit } \\
\text { Limpasan } \\
\left(\mathrm{m}^{3} / \mathrm{s}\right)\end{array}$ & Keterangan \\
\hline \multirow{2}{*}{1} & Kiri & 35,17 & 0,4 & 0,4 & 0,0503 & 0,0087 & MEMENUHI \\
& Kanan & 35,17 & 0,4 & 0,4 & 0,0503 & 0,0059 & MEMENUHI \\
2 & Kiri & 49,23 & 0,4 & 0,4 & 0,0521 & 0,0077 & MEMENUHI \\
& Kanan & 49,23 & 0,4 & 0,4 & 0,0521 & 0,0051 & MEMENUHI \\
3 & Kiri & 26,59 & 0,4 & 0,4 & 0,0528 & 0,0232 & MEMENUHI \\
& Kanan & 26,59 & 0,4 & 0,4 & 0,0528 & 0,0155 & MEMENUHI \\
4 & Kiri & 30,49 & 0,4 & 0,4 & 0,0518 & 0,0030 & MEMENUHI \\
& Kanan & 30,49 & 0,4 & 0,4 & 0,0518 & 0,0050 & MEMENUHI \\
5 & Kiri & 103,22 & 0,4 & 0,4 & 0,0416 & 0,0099 & MEMENUHI \\
& Kanan & 103,22 & 0,4 & 0,4 & 0,0416 & 0,0130 & MEMENUHI \\
6 & Kiri & 58,62 & 0,4 & 0,4 & 0,0528 & 0,0124 & MEMENUHI \\
& Kanan & 58,62 & 0,4 & 0,4 & 0,0528 & 0,0160 & MEMENUHI \\
\hline
\end{tabular}


Tabel 3.Analisis saluran eksisitng (lanjutan)

\begin{tabular}{|c|c|c|c|c|c|c|c|}
\hline $\begin{array}{l}\text { No. } \\
\text { Saluran }\end{array}$ & $\begin{array}{l}\text { Posisi } \\
\text { saluran }\end{array}$ & $\begin{array}{l}\text { Panjang } \\
(\mathrm{m})\end{array}$ & $\begin{array}{l}\text { Lebar } \\
(\mathrm{m})\end{array}$ & $\begin{array}{l}\text { Kedalaman } \\
\quad(\mathrm{m})\end{array}$ & $\begin{array}{c}\text { Debit } \\
\text { Eksisiting } \\
\left(\mathrm{m}^{3} / \mathrm{s}\right)\end{array}$ & $\begin{array}{c}\text { Debit } \\
\text { Limpasan } \\
\left(\mathrm{m}^{3} / \mathrm{s}\right)\end{array}$ & Keterangan \\
\hline \multirow{2}{*}{7} & Kiri & 62,43 & 0,4 & 0,4 & 0,0422 & 0,0058 & MEMENUHI \\
\hline & Kanan & 62,43 & 0,4 & 0,4 & 0,0422 & 0,0074 & MEMENUHI \\
\hline \multirow{2}{*}{8} & Kiri & 25,96 & 0,4 & 0,4 & 0,0535 & 0,0196 & MEMENUHI \\
\hline & Kanan & 25,96 & 0,4 & 0,4 & 0,0535 & 0,0274 & MEMENUHI \\
\hline \multirow{2}{*}{9} & Kiri & 18,49 & 0,4 & 0,4 & 0,0448 & 0,0021 & MEMENUHI \\
\hline & Kanan & 18,49 & 0,4 & 0,4 & 0,0448 & 0,0030 & MEMENUHI \\
\hline \multirow{2}{*}{10} & Kiri & 10,99 & 0,4 & 0,4 & 0,0368 & 0,0137 & MEMENUHI \\
\hline & Kanan & 10,99 & 0,4 & 0,4 & 0,0368 & 0,0148 & MEMENUHI \\
\hline \multirow{2}{*}{11} & Kiri & 27,37 & 0,4 & 0,4 & 0,0521 & 0,0055 & MEMENUHI \\
\hline & Kanan & 27,37 & 0,4 & 0,4 & 0,0521 & 0,0097 & MEMENUHI \\
\hline \multirow{2}{*}{12} & Kiri & 81,34 & 0,4 & 0,4 & 0,0478 & 0,0088 & MEMENUHI \\
\hline & Kanan & 81,34 & 0,4 & 0,4 & 0,0478 & 0,0090 & MEMENUHI \\
\hline \multirow{2}{*}{13} & Kiri & 118,67 & 0,4 & 0,4 & 0,0354 & 0,0105 & MEMENUHI \\
\hline & Kanan & 118,67 & 0,4 & 0,4 & 0,0354 & 0,0106 & MEMENUHI \\
\hline \multirow{2}{*}{14} & Kiri & 21,74 & 0,4 & 0,4 & 0,0413 & 0,0377 & MEMENUHI \\
\hline & Kanan & 21,74 & 0,4 & 0,4 & 0,0413 & 0,0314 & MEMENUHI \\
\hline \multirow{2}{*}{15} & Kiri & 114,88 & 0,4 & 0,4 & 0,0377 & 0,0140 & MEMENUHI \\
\hline & Kanan & 114,88 & 0,4 & 0,4 & 0,0377 & 0,0182 & MEMENUHI \\
\hline \multirow{2}{*}{16} & Kiri & 11,3 & 0,4 & 0,4 & 0,0513 & 0,0415 & MEMENUHI \\
\hline & Kanan & 11,3 & 0,4 & 0,4 & 0,0513 & 0,0405 & MEMENUHI \\
\hline \multirow{2}{*}{17} & Kiri & 39,1 & 0,4 & 0,4 & 0,0436 & 0,0119 & MEMENUHI \\
\hline & Kanan & 39,1 & 0,4 & 0,4 & 0,0436 & 0,0186 & MEMENUHI \\
\hline \multirow{2}{*}{18} & Kiri & 74,02 & 0,4 & 0,4 & 0,0470 & 0,0085 & MEMENUHI \\
\hline & Kanan & 74,02 & 0,4 & 0,4 & 0,0470 & 0,0116 & MEMENUHI \\
\hline \multirow{2}{*}{19} & Kiri & 15,91 & 0,4 & 0,4 & 0,0483 & 0,0453 & MEMENUHI \\
\hline & Kanan & 15,91 & 0,4 & 0,4 & 0,0483 & 0,0443 & MEMENUHI \\
\hline \multirow{2}{*}{20} & Kiri & 89,64 & 0,4 & 0,4 & 0,0353 & 0,0184 & MEMENUHI \\
\hline & Kanan & 89,64 & 0,4 & 0,4 & 0,0353 & 0,0240 & MEMENUHI \\
\hline \multirow{2}{*}{21} & Kiri & 15,49 & 0,4 & 0,4 & 0,0490 & 0,0480 & MEMENUHI \\
\hline & Kanan & 15,49 & 0,4 & 0,4 & 0,0490 & 0,0456 & MEMENUHI \\
\hline \multirow{2}{*}{22} & Kiri & 38,05 & 0,4 & 0,4 & 0,0442 & 0,0209 & MEMENUHI \\
\hline & Kanan & 38,05 & 0,4 & 0,4 & 0,0442 & 0,0273 & MEMENUHI \\
\hline \multirow{2}{*}{23} & Kiri & 63,29 & 0,4 & 0,4 & 0,0460 & 0,0079 & MEMENUHI \\
\hline & Kanan & 63,29 & 0,4 & 0,4 & 0,0460 & 0,0086 & MEMENUHI \\
\hline \multirow{2}{*}{24} & Kiri & 14,55 & 0,4 & 0,4 & 0,0505 & 0,0475 & MEMENUHI \\
\hline & Kanan & 14,55 & 0,4 & 0,4 & 0,0505 & 0,0448 & MEMENUHI \\
\hline \multirow{2}{*}{25} & Kiri & 61,98 & 0,4 & 0,4 & 0,0513 & 0,0202 & MEMENUHI \\
\hline & Kanan & 61,98 & 0,4 & 0,4 & 0,0513 & 0,0291 & MEMENUHI \\
\hline
\end{tabular}


Tabel 3.Analisis saluran eksisitng (lanjutan)

\begin{tabular}{|c|c|c|c|c|c|c|c|}
\hline $\begin{array}{c}\text { No. } \\
\text { Saluran }\end{array}$ & $\begin{array}{c}\text { Posisi } \\
\text { saluran }\end{array}$ & $\begin{array}{c}\text { Panjang } \\
\text { (m) }\end{array}$ & $\begin{array}{l}\text { Lebar } \\
(\mathrm{m})\end{array}$ & $\begin{array}{l}\text { Kedalaman } \\
\text { (m) }\end{array}$ & $\begin{array}{c}\text { Debit } \\
\text { Eksisiting } \\
\left(\mathrm{m}^{3} / \mathrm{s}\right)\end{array}$ & $\begin{array}{c}\text { Debit } \\
\text { Limpasan } \\
\left(\mathrm{m}^{3} / \mathrm{s}\right)\end{array}$ & Keterangan \\
\hline \multirow{2}{*}{26} & Kiri & 55,83 & 0,4 & 0,4 & 0,0258 & 0,0231 & MEMENUHI \\
\hline & Kanan & 55,83 & 0,4 & 0,4 & 0,0258 & 0,0202 & MEMENUHI \\
\hline \multirow{2}{*}{27} & Kiri & & & & & & \\
\hline & Kanan & 98,06 & 0,3 & 0,4 & 0,0117 & 0,1131 & TIDAK MEMENUHI \\
\hline \multirow{2}{*}{28} & Kiri & 54,93 & 0,4 & 0,4 & 0,0520 & 0,0096 & MEMENUHI \\
\hline & Kanan & 54,93 & 0,4 & 0,4 & 0,0520 & 0,0029 & MEMENUHI \\
\hline \multirow{2}{*}{29} & Kiri & & & & & & \\
\hline & Kanan & 38,75 & 0,4 & 0,4 & 0,0536 & 0,0033 & MEMENUHI \\
\hline \multirow{2}{*}{30} & Kiri & & & & & & \\
\hline & Kanan & 39,59 & 0,3 & 0,4 & 0,0185 & 0,1446 & TIDAK MEMENUHI \\
\hline \multirow{2}{*}{31} & Kiri & 66,85 & 0,4 & 0,4 & 0,0471 & 0,0115 & MEMENUHI \\
\hline & Kanan & 66,85 & 0,4 & 0,4 & 0,0471 & 0,0118 & MEMENUHI \\
\hline \multirow{2}{*}{32} & Kiri & & & & & & \\
\hline & Kanan & 40,37 & 0,4 & 0,4 & 0,0525 & 0,0117 & MEMENUHI \\
\hline \multirow{2}{*}{33} & Kiri & & & & & & \\
\hline & Kanan & 52,78 & 0,3 & 0,4 & 0,0160 & 0,1911 & TIDAK MEMENUHI \\
\hline \multirow{2}{*}{34} & Kiri & 324,64 & 0,4 & 0,4 & 0,0478 & 0,0407 & MEMENUHI \\
\hline & Kanan & 324,64 & 0,4 & 0,4 & 0,0478 & 0,0330 & MEMENUHI \\
\hline \multirow{2}{*}{35} & Kiri & 68,46 & 0,4 & 0,4 & 0,0329 & 0,0157 & MEMENUHI \\
\hline & Kanan & 68,46 & 0,4 & 0,4 & 0,0329 & 0,0078 & MEMENUHI \\
\hline 36 & $\begin{array}{c}\text { Kiri } \\
\text { Kanan }\end{array}$ & 73,58 & 0,3 & 0,4 & 0,0136 & 0,1103 & TIDAK MEMENUHI \\
\hline 37 & $\begin{array}{c}\text { Kiri } \\
\text { Kanan }\end{array}$ & 323,1 & 0,3 & 0,4 & 0,0123 & 0,1523 & TIDAK MEMENUHI \\
\hline 38 & $\begin{array}{c}\text { Kiri } \\
\text { Kanan }\end{array}$ & 51,33 & 1,0 & 1,0 & 0,3599 & 0,2139 & MEMENUHI \\
\hline 39 & $\begin{array}{c}\text { Kiri } \\
\text { Kanan }\end{array}$ & 48,77 & 1,0 & 1,0 & 0,3692 & 0,2174 & MEMENUHI \\
\hline 40 & $\begin{array}{c}\text { Kiri } \\
\text { Kanan }\end{array}$ & 38,8 & 1,0 & 1,0 & 0,4139 & 0,2273 & MEMENUHI \\
\hline 41 & $\begin{array}{c}\text { Kiri } \\
\text { Kanan }\end{array}$ & 45,3 & 1,0 & 1,0 & 0,3831 & 0,2243 & MEMENUHI \\
\hline 42 & $\begin{array}{c}\text { Kiri } \\
\text { Kanan }\end{array}$ & 330,57 & 0,3 & 0,4 & 0,0287 & 0,1614 & TIDAK MEMENUHI \\
\hline 43 & $\begin{array}{c}\text { Kiri } \\
\text { Kanan }\end{array}$ & 38,81 & 1,0 & 1,0 & 0,4139 & 0,2985 & MEMENUHI \\
\hline
\end{tabular}

Dari Tabel 3 dapat dilihat pada kolom keterangan ada 6 dari 73 saluaran yang tidak memenuhi debit limpasan yang terjadi akibat curah hujan periode ulang 2 tahun, maka dapat dibuat peta saluran untuk saluran yang memenuhi dan saluran yang tidak memenuhi seperti pada Gambar 3. 


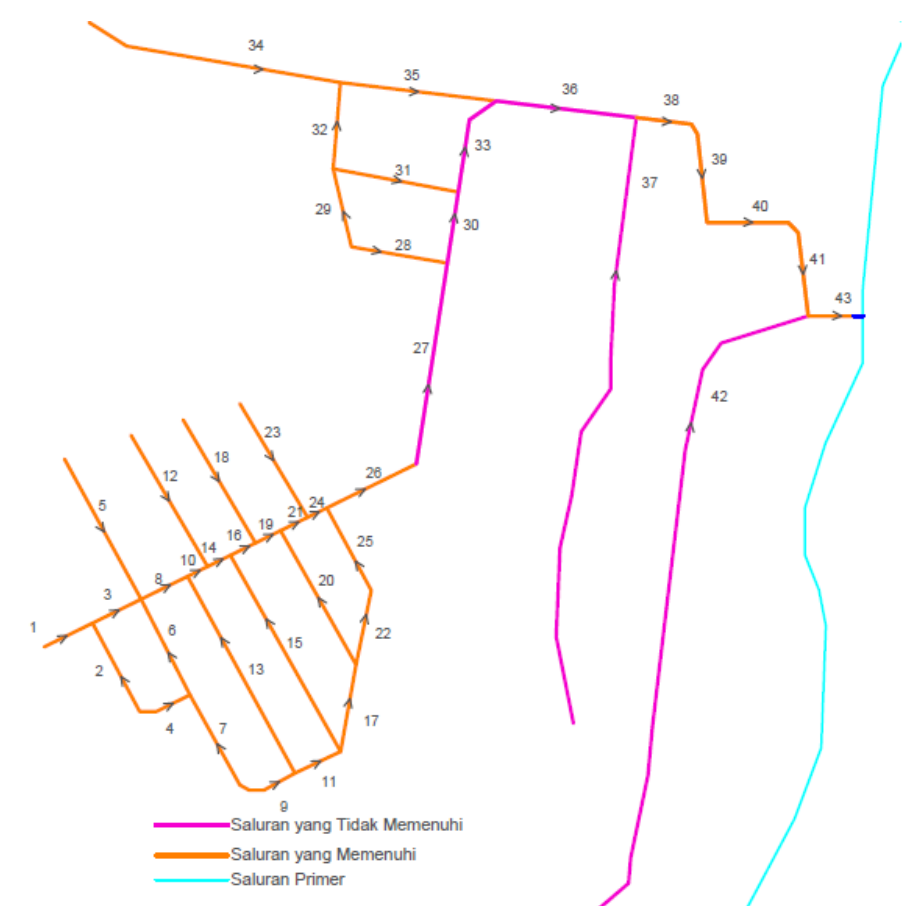

Gambar 3. Saluran yang banjir periode ulang 2 tahun

\section{Perencanaan saluran rencana}

Berdasarkan hasil dari Tabel 3, 6 dari 73 saluran tidak dapat menampung debit akibat curah hujan yang terjadi, maka dilakukan desain ulang untuk saluran eksisting yang tidak mampu menampung debit rancangan, dilihat pada Tabel 4.

Tabel 4. Perbandingan dimensi saluran eksiting dan saluran rencana

\begin{tabular}{ccccccc}
\hline \multirow{2}{*}{$\begin{array}{c}\text { No. } \\
\text { Saluran }\end{array}$} & Posisi & Panjang & \multicolumn{2}{c}{ Saluran Eksisting } & \multicolumn{2}{c}{ Saluran Rencana } \\
\cline { 5 - 7 } & Saluran & $(\mathrm{m})$ & $\begin{array}{c}\text { Lebar } \\
(\mathrm{m})\end{array}$ & $\begin{array}{c}\text { Kedalaman } \\
(\mathrm{m})\end{array}$ & $\begin{array}{c}\text { Lebar } \\
(\mathrm{m})\end{array}$ & $\begin{array}{c}\text { Kedalaman } \\
(\mathrm{m})\end{array}$ \\
\hline 27 & Kanan & 98,06 & 0,3 & 0,4 & 0,6 & 0,6 \\
30 & Kanan & 39,59 & 0,3 & 0,4 & 0,6 & 0,6 \\
33 & Kanan & 52,78 & 0,3 & 0,4 & 0,7 & 0,6 \\
36 & Kiri & 73,58 & 0,3 & 0,4 & 0,6 & 0,6 \\
37 & Kiri & 323,1 & 0,3 & 0,4 & 0,6 & 0,6 \\
42 & Kiri & 330,57 & 0,3 & 0,4 & 0,6 & 0,6 \\
\hline
\end{tabular}

Perbandingan debit saluran rencana dengan saluran eksisting dapat dilihat pada Tabel 5.

Tabel 5. Perbandingan debit saluran eksiting dan saluran rencana

\begin{tabular}{ccccc}
\hline $\begin{array}{c}\text { No. } \\
\text { Saluran }\end{array}$ & $\begin{array}{c}\text { Posisi } \\
\text { Saluran }\end{array}$ & $\begin{array}{c}\text { Debit } \\
\text { Limpasan }\end{array}$ & $\begin{array}{c}\text { Debit } \\
\text { Rencana }\end{array}$ & Keterangan \\
\hline 27 & Kanan & 0,1131 & 0,1183 & MEMENUHI \\
30 & Kanan & 0,1446 & 0,1861 & MEMENUHI \\
33 & Kanan & 0,1911 & 0,1990 & MEMENUHI \\
36 & Kiri & 0,1103 & 0,1365 & MEMENUHI \\
37 & Kiri & 0,1523 & 0,2303 & MEMENUHI \\
42 & Kiri & 0,1614 & 0,1822 & MEMENUHI \\
\hline
\end{tabular}


Pemodelan saluran 36 kiri eksiting dengan saluran 36 kiri rencana menggunakan aplikasi HEC-RAS dapat dilihat pada Gambar 4 dan Gambar 5

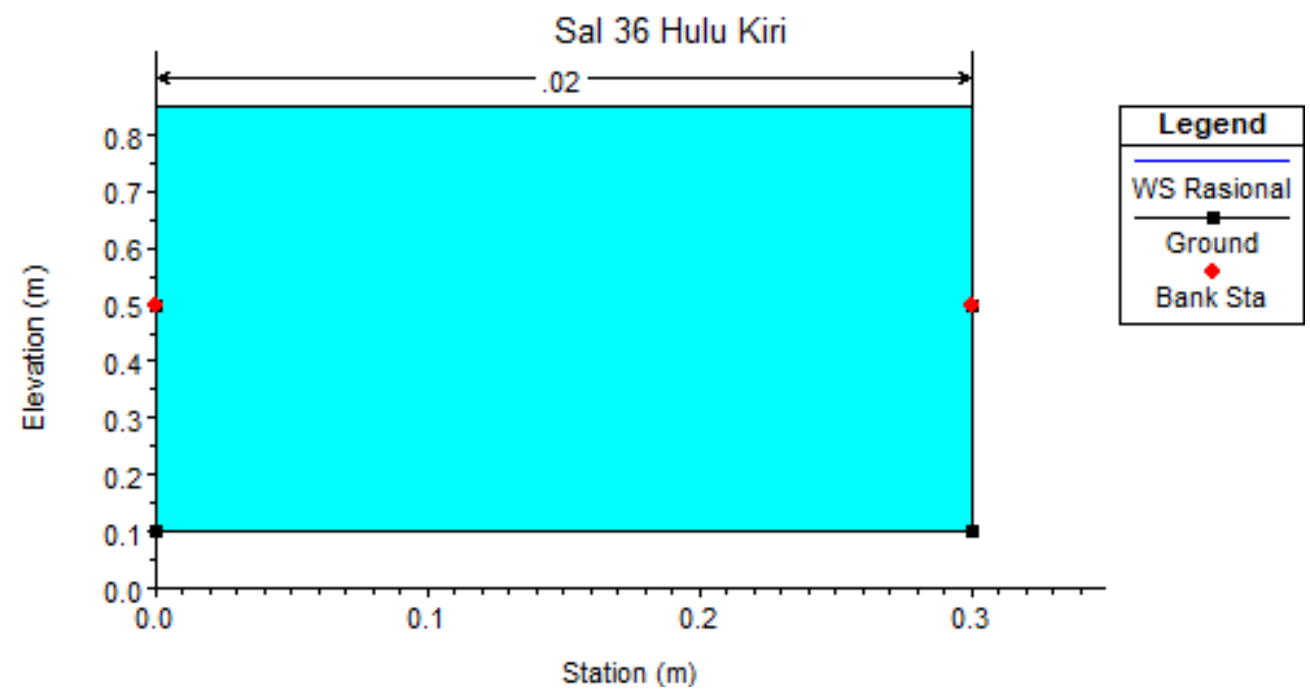

Gambar 4. Pemodelan saluran 36 kiri hulu eksisting

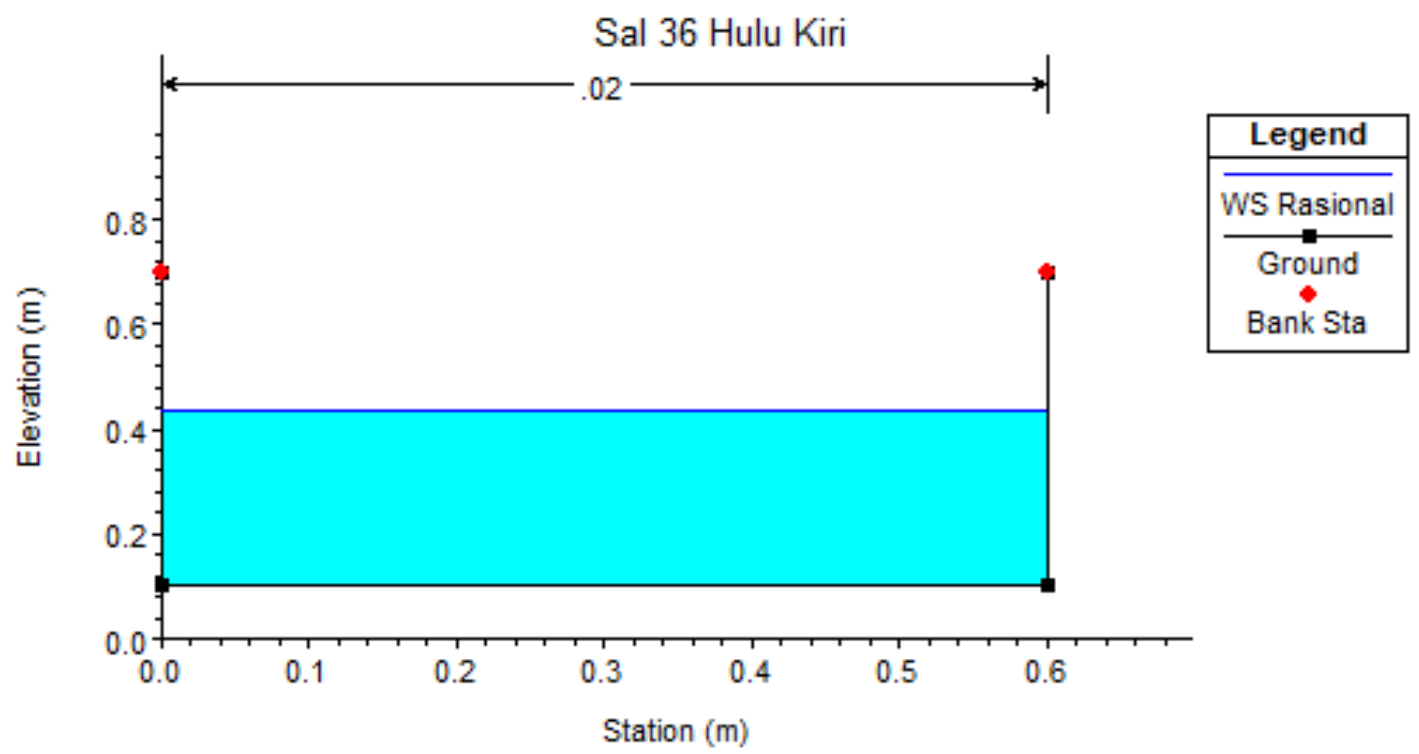

Gambar 5. Pemodelan saluran 36 kiri hulu Rencana

Pada Gambar 4 dan 5, titik yamg berwarna merah adalah batas tinggi saluran, titik yang bewarna hitam adalah batas permukaan dasar saluran, sedangkan warna biru adalah besar debit air yang terjadi. Dari hasil pemodelan dapat dilihat saluran eksisting (Gambar 4) tidak mampu menampung debit limpasan, sedangkan saluran rencana (Gambar 5) dapat menapung debit limpasan.

\section{KESIMPULAN DAN SARAN}

\section{Kesimpulan}

Dari hasil analisis dapat disimpulkan sebagai berikut:

1. Pada periode ulang 2 tahun adalah 67 saluran yang memenuhi dan 6 saluran tidak memenuhi, pada periode ulang 5 tahun terdapat 58 saluran yang memenuhi dan 15 saluran tidak memnuhi, pada periode ulang 10 tahun terdapat 54 saluran yang memenuhi dan 19 saluran tidak memenuhi, pada periode ulang 20 tahun terdapat 52 saluran yang memenuhi dan 21 saluran tidak memenuhi, dan pada tanggal 25 Februari 2020 terdapat 61 saluran yang memenuhi dan 12 saluran tidak memenuhi. 
2. Dalam perhitungan debit saluran eksisting curah hujan yang digunakan adalah periode ulang 2 tahun karena berdasarkan Permen PU Nomor 12/PRT/M/2014 tentang Penyelenggaraan Sistem Drainase Perkotaan, periode ulang yang digunakan untuk daerah tangkapan air kurang dari 10 Ha di kota metropolitan adalah 2 tahun (Kementerian Pekerjaan Umum).

3. Penyebab utama dari terjadinya genangan pada Kelurahan Jatake, Kota Tangerang adalah kapasitas saluran drainase yang tidak mampu menampung debit akibat curah hujan yang terjadi, selain itu terdapat juga faktor lain yang menyebabkan genangan yaitu kondisi kontur pada daerah tersebut memiliki kemiringan yang cukup landai, memungkinkan air mengalir lambat dan sampah yang cukup banyak sehingga menghambat aliran air.

\section{Saran}

Berdasarkan analisis yang dilakukan, disarankan mengubah saluran darinase sesuai dengan hasil perhiungan saluran rencana pada Tabel 5, dan juga melakukan pembersihan atau pengerukan pada saluran yang ada secara rutin, agar tidak terjadi sedimen pada dasar saluran serta sampah yang dapat mengganggu aliran air. Penelitian ini dilakukan pada saat pandemi Covid-19 sehingga data yang diperoleh ada yang melalui survei pribadi. Disarankan untuk penelitian kedepannya dapat menggunakan theodolite dalam pengukuran kemiringan dasar saluran

\section{DAFTAR PUSTAKA}

Badan Pusat Statistik Kota Tangerang. “Kecamatan Jati uwung dalam angka 2020.” (2020).

Badan Standardisasi Nasional. "SNI 2415:2016." Tata cara perhitungan debit banjir rencana (2016).

Badan Standardisasi Nasional “SNI 8456:2017.” Sumur Dan Parit Resapan Hujan (2017).

Flemming, George. Flood risk management: Learning to live with rivers . London: Thomas Telford, 2002.

Istiarto. Modul Pelatihan HEC-RAS. Yogyakarta: Universitas Gajah Mada, 2010.

Kementerian Pekerjaan Umum. "Penyelenggaraan Sistem Drainase Perkotaan.” 12/PRT/M/2014 (2014).

Peraturan Pemerintah Republik Indonesia Nomor 38 Tahun, 2011

Upono, Togani Cahyadi and Rini Kusumawardani. "Pemilihan Distribusi Probabilitas Pada Analisa Hujan dengan Metode Goodness of Fit Test." Jurnal Teknik Sipil dan Perencanaan, Nomor 2 Volume 18 (2016): 141143. 